Dawson. J.W. \& Strazicich, M.C. (2010). Time-series tests of income convergence with two structural breaks: evidence from 29 countries, Applied Economics Letters, 17(9): 909-912 (June 2010). Published by Taylor \& Francis (ISSN: 1350-4851). DOI: 10.1080/13504850802584807.

\title{
Time-series tests of income convergence with two structural breaks: evidence from 29 countries
}

John W. Dawson and Mark C. Strazicich

\begin{abstract}
This article uses data on real per capita incomes from 1900 to 2001 to test for stochastic convergence in a diverse group of 29 countries. We utilize LM unit root tests to endogenously determine the number and location of structural breaks for each country. These tests avoid spurious rejections that can occur in Dickey-Fuller-type endogenous break tests used in many previous studies. We find significant evidence that incomes are stochastically converging in 23 of the countries, with World War II most often identified as the time period of structural breaks.
\end{abstract}




\section{INTRODUCTION}

Since Friedman's (1992) criticism of cross-section tests of the convergence hypothesis, alternative time-series tests for income convergence have been often explored. Such time-series tests frequently adopt unit root techniques to test for convergence. See, for example, studies by Carlino and Mills (1993), Loewy and Papell (1996), Li and Papell (1999), Strazicich et al. (2004) and Dawson and Sen (2007), among others. Carlino and Mills (1993) and Loewy and Papell (1996) use Augmented Dickey-Fuller (ADF)-type unit root tests and find support for income convergence among the US regions. Whereas Carlino and Mills (1993) utilize one exogenous and identical break in each region, Loewy and Papell (1996) find stronger support utilizing one endogenous break that is distinct to each region. Li and Papell (1999) employ an ADF-type unit root test with one endogenously determined break and find evidence of convergence in 14 of 16 OECD countries. Strazicich et al. (2004) utilize a two-break LM unit root test to test for convergence in 15 OECD countries for the time period 1870-1994 and find evidence of convergence in nearly all countries. Dawson and Sen (2007) utilize ADF-type unit root tests with one endogenously determined break and find evidence of convergence in 21 countries using a sample of 29 OECD and non-OECD countries over the period 1900 to 2001.

In this article, we apply the two-break LMunit root test used by Strazicich et al. (2004) to the dataset considered in Dawson and Sen (2007). In comparison to Li and Papell (1999) and Strazicich et al. (2004), we consider a larger and more diverse group of countries. In addition, whereas Dawson and Sen (2007) consider one structural break, we allow up to two structural breaks. Perhaps most important, we utilize LM unit root tests that are not subject to spurious rejections, which can occur in ADF-type unit root tests in the presence of a unit root with break(s). As such, an important contribution of this article is to examine the robustness of previous studies that utilize ADF-type endogenous break unit root tests.

\section{TIME-SERIES TESTS FOR CONVERGENCE}

Most time-series tests of convergence are related to the notion of 'stochastic convergence' as described in 
Carlino and Mills (1993). Stochastic convergence implies that shocks to the income of a given country relative to the average income across a group of countries will be temporary. Thus, a common test for stochastic convergence involves testing for a unit root in the log of the ratio of per capita income relative to the group average. Failure to reject the unit root null hypothesis is evidence of divergence, whereas rejection of the unit root null supports stochastic convergence. The standard approach to test for a unit root involves performing ADF unit root tests.

A potential problem common to the ADF-type endogenous break unit root tests is that they typically derive their critical values while assuming no break(s) under the null hypothesis. This assumption leads to size distortions and over-rejections in the presence of a unit root with break(s) (see, e.g. Nunes et al., 1997; Lee and Strazicich, 2001; Perron, 2006). As a result, 'spurious rejections' in the use of ADF-type endogenous break tests can lead researchers to conclude that a time series is trend-break stationary when, in fact, the series is nonstationary with break(s). Lee and Strazicich (2003) propose a LM unit root test that avoids this potential problem, so that a rejection of the null unambiguously indicates a trend-break stationary series.

The test allows for two endogenously determined breaks in the level and trend slope and utilizes $k^{*}$ lagged first-differenced terms to correct for serial correlation (with $\mathrm{k}^{*}$ determined by a 'general-to-specific' procedure).

Our tests for stochastic convergence apply this two-break LM unit root test to the relative income data examined previously by Dawson and Sen (2007). The underlying source data from Maddison (1995, 2003) consist of annual time series on per capita real GDP over the period 1900 to 2001 for the following countries: Argentina, Australia, Austria, Belgium, Brazil, Canada, Chile, Columbia, Denmark, Finland, France, Germany, India, Italy, Japan,Mexico, the Netherlands, New Zealand, Norway, Peru, Portugal, Spain, Sri Lanka, Sweden, Switzerland, the United Kingdom, the United States, Uruguay and Venezuela.1 For each country, we examine the natural logarithm of the individual country's per capita real GDP divided by the aggregate per capita real GDP, which is calculated by summing real GDP from the 29 countries and dividing by the total population of these countries. 
Table 1. Two-break LM unit root tests, 1900-2001

\begin{tabular}{llll}
\hline Country & $T_{B 1}, T_{B 2}$ & Test statistic & $\begin{array}{l}\lambda \text { used for critical } \\
\text { values }\end{array}$ \\
\hline Argentina & 1994,1985 & $-5.497^{*}$ & $(0.4,0.8)$ \\
Australia & $1932^{\mathrm{a}}, 1954$ & -5.021 & $(0.4,0.6)$ \\
Austria & 1943,1953 & $-6.195^{* *}$ & $(0.4,0.6)$ \\
Belgium & 1917,1940 & $-6.322^{* * *}$ & $(0.2,0.4)$ \\
Brazil & 1973,1979 & $-6.036^{* *}$ & $(0.6,0.8)$ \\
Canada & 1916,1943 & $-5.582^{*}$ & $(0.2,0.4)$ \\
Chile & 1947,1986 & $-6.158^{* *}$ & $(0.4,0.8)$ \\
Columbia & 1934,1972 & $-5.392^{*}$ & $(0.4,0.8)$ \\
Denmark & 1938,1947 & $-7.253^{* * *}$ & $(0.4,0.6)$ \\
Finland & 1913,1928 & $-5.679^{* *}$ & $(0.2,0.4)$ \\
France & 1938,1948 & $-7.578^{* * *}$ & $(0.4,0.6)$ \\
Germany & 1943,1955 & $-5.580^{*}$ & $(0.4,0.6)$ \\
India & 1940,1980 & $-5.621^{*}$ & $(0.4,0.8)$ \\
Italy & 1941,1948 & $-5.714^{* *}$ & $(0.4,0.6)$ \\
Japan & 1943,1964 & -4.962 & $(0.4,0.6)$ \\
Mexico & 1931,1986 & $-5.343^{*}$ & $(0.4,0.8)$ \\
Netherlands & 1939,1947 & $-7.907^{* * *}$ & $(0.4,0.6)$ \\
New Zealand & 1924,1946 & $-5.570^{*}$ & $(0.2,0.4)$ \\
Norway & $1931,1940^{\mathrm{a}}$ & $-5.478^{*}$ & $(0.2,0.4)$ \\
Peru & 1952,1986 & $-5.818^{* *}$ & $(0.6,0.8)$ \\
Portugal & 1913,1964 & -4.818 & $(0.2,0.6)$ \\
Spain & 1934,1962 & -4.880 & $(0.4,0.6)$ \\
Sri Lanka & $1929,1971^{\mathrm{a}}$ & -4.964 & $(0.2,0.6)$ \\
Sweden & 1915,1947 & $-6.067^{* *}$ & $(0.2,0.4)$ \\
Switzerland & $1909^{\mathrm{a}}, 1949$ & $-5.520^{*}$ & $(0.2,0.4)$ \\
UK & 1931,1969 & -4.594 & $(0.4,0.6)$ \\
USA & 1938,1957 & $-5.544^{*}$ & $(0.4,0.6)$ \\
Uruguay & 1957,1972 & -5.176 & $(0.6,0.8)$ \\
Venezuela & 1924,1959 & $-6.100^{* *}$ & $(0.2,0.6)$ \\
\hline Nos & & & \\
\hline
\end{tabular}

Notes: $T_{B 1}$ and $T_{B 2}$ denote the break dates. $\lambda$ denotes the relative position of the break points. Critical values at different break points ( $\lambda$-values) for a sample size $T=100$ are reported in Strazicich et al. (2004), Table 1. Critical values at other break points can be interpolated.

*,** and ${ }^{* * *}$ denote significance at the 10,5 and $1 \%$ levels, respectively.

${ }^{a}$ Denotes that the identified break point was not significant at the $10 \%$ level.

The two-break LM unit root test results are reported in Table 1 . In 22 of the 29 relative income series, the unit root null and, thus divergence, is rejected at the $10 \%$ significance level. The seven countries for which we cannot reject the unit root null are Australia, Japan, Portugal, Spain, Sri Lanka, the UK and Uruguay. Further examination of these results reveals that two structural breaks in level and/or trend are significant (t-values significant at 10\%) in 25 countries, whereas only one structural break is significant in the remaining four countries (Australia, 
Norway, Sri Lanka and Switzerland). The most frequently identified time period of breaks is in the years 1938-1948 surrounding World War II (approximately $35 \%$ of the breaks). Also noteworthy is that five Latin American countries (Argentina, Brazil, Chile, Mexico and Peru) have structural breaks in their relative income during the period 1979-1986. This period is well known to be one of debt crisis and economic collapse for many Latin American countries.

Table 2. One-break LM unit root tests, 1900-2001

\begin{tabular}{llll}
\hline Country & $T_{B}$ & Test statistic & $\begin{array}{l}\lambda \text { used for critical } \\
\text { values }\end{array}$ \\
\hline Australia & $1978^{\mathrm{a}}$ & $-4.283^{*}$ & $0.8(=0.2)$ \\
Norway & 1981 & $-4.852^{* *}$ & $0.8(=0.2)$ \\
Sri Lanka & 1977 & -3.258 & $0.8(=0.2)$ \\
Switzerland & 1949 & $-5.123^{* * * *}$ & 0.5 \\
\hline
\end{tabular}

Notes: $T_{B}$ denotes the break date. $\lambda$ denotes the relative position of the break point. Critical values at different break points ( $\lambda$-values) for a sample size $T=100$ are reported in Strazicich et al. (2004), Table 2. Critical values at other break points can be interpolated.

*, ** and *** denote significance at the 10,5 and $1 \%$ levels, respectively.

${ }^{a}$ Denotes that the identified break point was not significant at the $10 \%$ level.

As one-break unit root tests appear to be more appropriate for Australia, Norway, Sri Lanka and Switzerland, we perform additional tests for these four countries using the one-break LM unit root test of Lee and Strazicich (2004). These results are summarized in Table 2. For Norway and Switzerland, countries for which the unit root null was rejected at the $10 \%$ level in the two-break test, we can now reject the unit root null at the stronger 5 and $1 \%$ levels, respectively. The breaks for these countries are significant at the $10 \%$ level. Australia and Sri Lanka were countries for which we could not reject the unit root null hypothesis in the two-break tests. Using the onebreak test, we can now reject the unit root null in Australia at the $10 \%$ level. However, the break is not significant at the $10 \%$ level. We are still not able to reject the unit root null for Sri Lanka, although the break is significant at the $10 \%$ level. 
As the estimated break for Australia is not significant, a unit root test without a break may be more appropriate. We consider the conventional ADF test in this case. When both an intercept and trend are included in the test equation, the unit root null cannot be rejected at the $10 \%$ level. However, the trend term is not statistically significant at the $10 \%$ level. When the trend term is removed, the unit root null is rejected at the $5 \%$ level with a t-test statistic of -2.93 . Thus, including Australia, we can reject divergence in 23 (79\%) of the 29 countries.

In comparison with the results reported in Dawson and Sen (2007), we find more evidence of stochastic convergence. We find evidence to reject divergence in 23 countries as compared to their 21 . Both studies agree on the lack of stochastic convergence in the following four countries: Japan, Portugal, Sri Lanka and the UK. The studies also agree on the lack of a significant break for Australia.

\section{CONCLUDING REMARKS}

This article tests for stochastic convergence using long-span data on the relative real per capita incomes of 29 OECD and non-OECD countries - the largest and most diverse group of countries for which long-span data are currently available. We utilize LM unit root tests that allow for two endogenously determined structural breaks in each country's relative income series. At least one significant structural break is found in all but one country (Australia) and World War II is the most often identified time period of breaks. Overall, our findings provide significant evidence of stochastic convergence in 23 of the 29 countries. The LM unit root tests provide an important robustness check that avoids the potential spurious rejections with ADF-type tests.

\section{REFERENCES}

Carlino, G. and Mills, L. (1993) Are US regional economies converging? A time series analysis, Journal of Monetary Economics, 32, 335-46.

Dawson, J. W. and Sen, A. (2007) New evidence on the convergence of international income from a group of 29 countries, Empirical Economics, 33, 199-230. 
Friedman, M. (1992) Do old fallacies ever die?, Journal of Economic Literature, 30, 2129-32.

Lee, J. and Strazicich, M. C. (2001) Break point estimation and spurious rejections with endogenous unit root tests, Oxford Bulletin of Economics and Statistics, 63, 535-58.

Lee, J. and Strazicich, M. C. (2003) Minimum LM unit root test with two structural breaks, The Review of Economics and Statistics, 63, 1082-9.

Lee, J. and Strazicich, M. C. (2004) Minimum LM unit root test, Working Paper, Department of Economics, Appalachian State University, Boone.

Li, Q. and Papell, D. (1999) Convergence of international output: time series evidence for 16 OECD countries, InternationalReview of Economics and Finance, 8, 267-80.

Loewy, M. B. and Papell, D. H. (1996) Are US regional incomes converging? Some further evidence, Journal of Monetary Economics, 38, 587-98.

Maddison, A. (1995) Monitoring the World Economy 1820-1992, OECD Development Center, Paris, France.

Maddison, A. (2003) The World Economy: Historical Statistics, Development Center Studies, Development Center for OECD, Paris, France.

Nunes, L., Newbold, P. and Kuan, C.-M. (1997) Testing for unit roots with breaks: evidence on the great crash and the unit root hypothesis reconsidered, Oxford Bulletin of Economics and Statistics, 59, 435-48.

Perron, P. (2006) Dealing with structural breaks, in New Palgrave Handbook of Econometrics, Vol. 1 (Eds)

T. C. Mills and K. Patterson, Macmillan, London, pp. 278-352.

Strazicich, M. C., Lee, J. and Day, E. (2004) Are incomes converging among OECD countries? Time series evidence with two structural breaks, Journal of Macroeconomics, 26, 131-45. 